DOI: $10.17516 / 1997-1370-0612$

УДК 72

\title{
Architectural Curvilinearity - Analysis of the Harbin Opera House Structural Solutions
}

\author{
Igor V. Kirichkov* \\ Siberian Federal University \\ Krasnoyarsk, Russian Federation \\ Dmitri Hvorostovsky Siberian State Academy of Arts \\ Krasnoyarsk, Russian Federation
}

Received 13.03.2020, received in revised form 28.05.2020, accepted 05.06.2020

\begin{abstract}
Curvilinear architecture has a rapid development in many countries of the world. This research article briefly describes the methods for forming curvilinear building structures indicating its advantages and disadvantages. It analyses the structural solutions of one of the most unique works of contemporary architecture - Harbin Opera House, designed by the Chinese architect Ma Yansong. After more than five years of research, the result shows that the level of technical skills, particularly relating to the construction of complex, unique objects, unfortunately, is still low. Huge opportunities for creating curvilinear architecture forms were not used. The traditional approach to the architectural design, including contemporary form creation methods, is absolutely wrong. The curvilinear architecture, as any other, requires development of its own, individual structural solutions.
\end{abstract}

Keywords: curvilinearity, spatial structures, Harbin Opera House, morphogenesis, folded forms, contemporary architecture, fold.

Research area: theory and history of architecture, restoration and reconstruction of historical and architectural heritage.

Citation: Kirichkov, I.V. (2020). Architectural curvilinearity - analysis of the Harbin Opera House. Structural solutions. J. Sib. Fed. Univ. Humanit. Soc. Sci., 13(6), 876-890. DOI: 10.17516/1997-13700612 .

\footnotetext{
(C) Siberian Federal University. All rights reserved

* Corresponding author E-mail address:kiri4kov@mail.ru ORCID: 0000-0002-5369-5825
} 


\section{Introduction}

Curvilinearity performs the main creation role in contemporary architecture. Forcing to the transformation of the construction of walls, roofs, slabs, it is also largely changing the image of architectural thinking, making it more flexible, able to overcome difficult barriers. The fold theory proposed by the French philosopher Gilles Deleuze became the theoretical foundation of curvilinearity ("The Fold. Leibniz and the Baroque", 1988), according to which "the world is likened to the original equation of the curve with an infinite line of inflection", where "each monad expresses the curve with its point of view." (Deleuze, 1997) The fold theory received the powerful development in architecture due to the efforts of the group of such famous architects as Peter Eisenman ("Folding in Time: The Singularity of Rebstock", 1993), Greg Lynn ("Architectural Curvilinearity. The Folded, the Pliant and the Supple", 1993), Jeffrey Kipnis ("Towards a New Architecture", 1993) and others. The curvilinear architecture is characterized by the resolute rejection from traditional aesthetics, based on symmetry, order, proportionality, presence of compositional centres, etc. If deconstructivism uses the contradiction method, the curvilinear architecture uses the method of flexibility and pliancy.

Chinese researches Pan Haixu (潘海迅) and Sun Yu (孙宇) note, that the curvilinear forms in architecture demonstrate the pursuit of humanism by an architect (建筑师追求人 性化的建筑形象). This is one of the most effective ways of organizing space. Curved lines are able to influence not only the architectural image as a whole - whether it is a large-scale urban planning ensemble or a small room, but also the psychology of people at a very high level (高层次上实现对人的心理关怀) (Pan Haixu, Sun Yu, 2006).

The research of the curvilinear forms in architecture, based on the analysis of buildings designed by the architectural company Foster \& Partners such as the Sage Music Centre in Gateshead, the American Air Museum in Duxford, the Faculty of Law at Cambridge University, The Great Court at the British Museum, and others, made by Faridah Adnan and Rodzyah Mohd Yunus from Malaysian Univer- sity of Technology, showed that "curvilinear forms of architecture have vital influence on environment-behaviour", including such factors as promoting communication, encouraging movement, lifting the spirit, aiding orientation, changing perception, enhancing social experience, increasing pleasure, supporting the sense of community, relieving the sense of distance and dissolving social boundaries (Adnan, Mohd Yunus, 2012).

The rapid development of the curvilinear architecture in the early 90 's of the $20^{\text {th }}$ century occurred due to the emergence of new building materials, improvement of construction equipment (installation mechanisms), introduction of digital technologies, stricter requirements for the projected objects, the desire to create new forms, the search for new means of expression and other important factors.

At present the curvilinear architecture is very popular in many countries around the world, including the Asian region - Japan, South Korea, Singapore, China. A huge interest to the curvilinearity is due to its ability to offer a large number of problems that are not solved anywhere yet. The talent of an engineer-architect opens fully only when he sets himself ambitious difficult goals.

\section{Curvilinear structures forming methods}

A curvilinear form in architectural design is achieved by several methods, each of them has both advantages and disadvantages. The first method - the simplest and the most common - is the creation of a curvilinear form structure using connection of separated straight elements - tubes, channels, I-beams, angles, etc. The connection nodes may be welded, bolted, and with the possibility of torsion of elements relatively to each other (demountable structures). One of the most frequently used nodes is a ball joint (spherical bearings that connect the control arms). Advantages of the separated straight elements connection method are the low-cost price, fast assembling, convenience of installation, etc. Disadvantages are the unevenness of internal forces transition, the emergence of numerous stress concentrators in the nodes that detrimentally effects both the local and the overall 
rigidity of the structure. The bearing capacity of this structure is extremely low. The second method - more labour-intensive, requiring a high level of engineering skills - is the creation of a curvilinear form structure using curved elements. Bending is carried out using a special profile bending (presses) machines. Advantages of this method are the structural integrity, a smooth transition of internal forces by reducing the number of nodes, a high aesthetic appeal. Disadvantages are the high-cost price, long time of manufacture, necessity in special machines, etc. The bearing capacity of this kind of structure, as a rule, is higher than the one created from the separated elements. The third method - effective in case of the construction of large-span structures (stadiums, bridges, etc.) - is the creation of a curvilinear form structure using shrouds (cables). Advantages of this method are the relatively low-cost price, high load-bearing capacity, big aesthetic appeal. Disadvantages are the installation complexity, the general instability - relatively low external influences cause significant deformations. Shrouds (cables) never fulfil the function of the load bearing element, but only serves as an auxiliary. Fragile materials (such as glass) usually are not used with shrouds. The fourth method - very specific, usually used in a region with soft climatic conditions - is the creation of a curvilinear form structure using membranes. Membranes, as a rule, are produced from such synthetic materials as polyester, fiberglass, polyvinyl chloride (PVC), polytetrafluoroethylene (PTFE), ethylene tetrafluoro-ethylene (ETFE) and others. (Kurshakova, 2008) Special chemical additives can increase the membranes fire protection. Advantages are the lightness, flexibility (elongation under a load up to $30 \%$ ), ability to withstand strong wind, snow loads, high aesthetic appeal. Disadvantages are the installation complexity (must provide the necessary tension across the membrane surface, otherwise it forms folds), general instability, relatively low durability (usually does not exceed 20 years). Membrane structures exist for a long time. It became widespread more than half a century ago. The fifth method - the most effective and the most technological - is the creation of a curvilinear form structure using volumetric structural elements - shells. Shells are one of the greatest inventions that nature has been able to create. It can fulfil a load bearing function and also serve as an auxiliary element. The bearing capacity of shell structures is very high, a minimal weight structure allows to cover a very large area. The span of the shell structures is the highest of all that exist in the world. The durability of shells is very high. For example, the sailing dome structure (diameter $31 \mathrm{~m}$ ) of Hagia Sophia in Constantinople (modern Istanbul), built during the time of the Byzantine Empire, exists for more than 1000 years already. The dome was destroyed by the earthquake, after this it was rebuilt by the Armenian architect Trdat in 989. However, despite such significant advantages, shell structures are rarely used in modern architecture, the reasons include the construction complexity, high labour-intensity, lack of engineering knowledges, technology backwardness and others.

The curvilinear architecture aspires to build "a new relationship between the material and geometry" as opposed to those that existed before. New technologies should make material production more cost-effective, "expanding its design possibilities" (Lynn, 1993).

\section{Harbin Opera House}

One of the most unique works of Contemporary Architecture - Harbin Opera House (Ch. 哈尔滨江北大剧院) - was designed by the Beijing architectural bureau (MAD Architects) under the leadership of Chinese architect Ma Yansong (Ch. 马岩松, born in 1975). (Fig. 1) The project has been implemented for five years. The first pile was hammered on October $15^{\text {th }}, 2010$, and the first musical concert dedicated to the cultural interaction between Russia and China, named "Melody of friendship" was held in the building on August $28^{\text {th }}$, 2015 (Ch. 友谊的旋律). The construction area amounts to $79,000 \mathrm{~m}^{2}$. The total estimated cost of the project calculated in 2012, including all the necessary infrastructure - roads, a square in front of the theatre, bridges over the river, landscape design, etc. - amounted to 1.88 bil- 


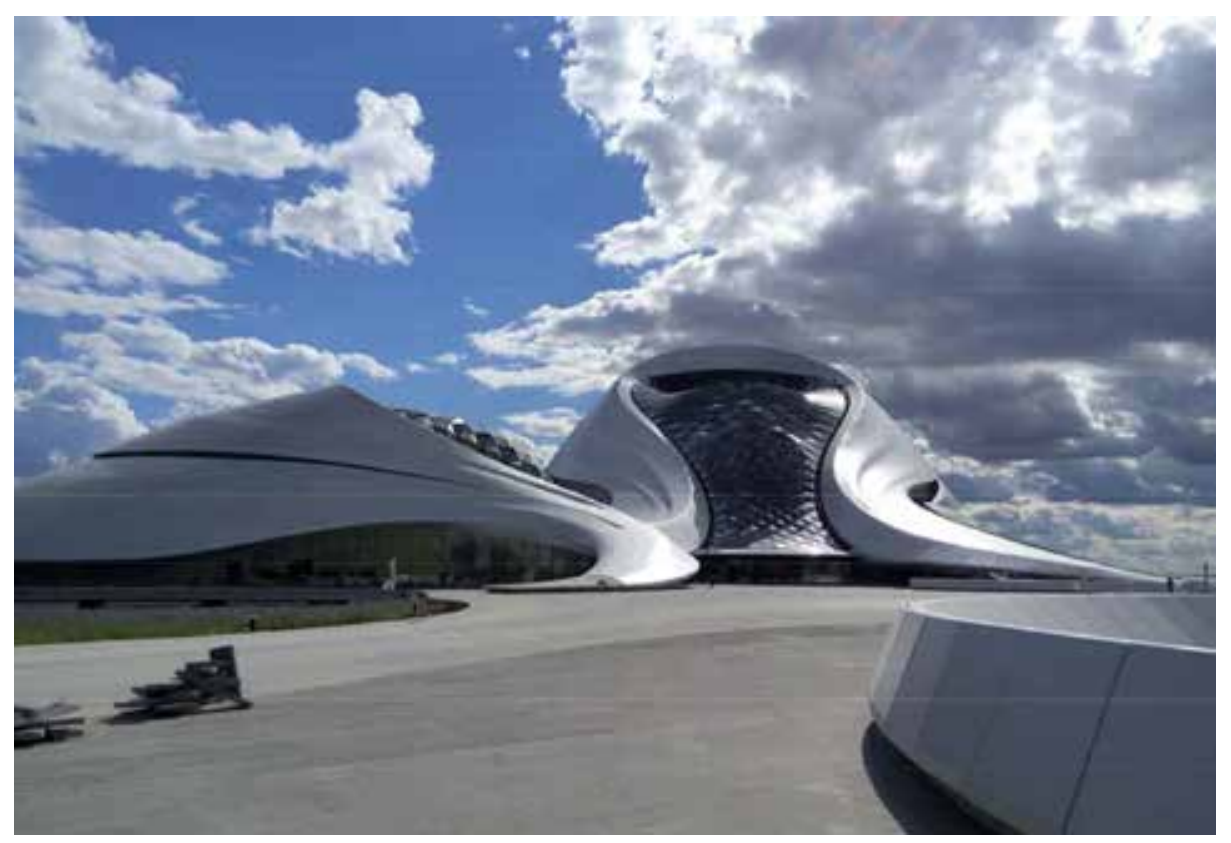

Fig. 1. Harbin Opera House. Author's photo, September 2015

lion yuan, which is about 310 million dollars. The total estimated cost of the theatre building is 1 billion yuan, about 167 million dollars. The project investor was Harbin Songbei Capital Development Group Co., Ltd. (Ch. 哈 尔滨松北投资发展集团有限公司)， construction monitoring was held by the Second Office of Songbei District Project Construction Management (Ch. 松北区项目建设管理第二 办公室), architectural design - by “MAD Architects” (Ch. MAD建筑事务所), Beijing Architectural Design and Research Institute (Ch. 北京市建筑设计研究院), building inspection by Zhejiang Jiangnan Project Management Co., Ltd. (Ch. 浙江江南工程管理股份有限公 司), construction by Beijing Construction Engineering Group Co., Ltd. (Ch. 北京建工集团 有限责任公司). The theatre is located in the middle of the Northern wetland shore of the Songhua River (Ch. 松花江, Songhuajiang) with an area of 180 ha. This area, due to the narrow paths over the water, began to be used as a park, and become a special "part of theatrical decoration." The landscape design was developed by the Beijing Turenscape Institute (Ch. 北京土人景观与规划设计研究院) (Han Peng, 2012).

\section{Space-planning solutions}

The building (height $56.48 \mathrm{~m}$ ), resembling a giant octopus shape, consists of two main parts connected with each other by a passage a large auditorium scaled to fit 1,600 spectators and a small one for 400 spectators. The lobby areas are situated in front of each auditorium and can be entered directly from the street. A lot of auxiliary facilities are located behind the stage space - dressing rooms, a rehearsal hall, a stage equipment storage room, etc., administrative offices and VIP zones with an area of $100 \mathrm{~m}^{2}$ are located at the higher floors; at the lower floors there is underground parking for 472 car places. The building has eight floors above ground with an area of $39,400 \mathrm{~m}^{2}$ and two underground floors - area of $19,000 \mathrm{~m}^{2}$. Lift shafts are equipped on both sides of the large auditorium from the first to the fourth floor (Fig. 2-4).

According to the author of the Harbin Opera House project, the form design is based on "the poetry of edge and surface", "softness and sharpness". The opera theatre "sculpted by wind and water", undergoing "synergistical blending with the surrounding nature", should become "a cultural centre of the future - a tre- 


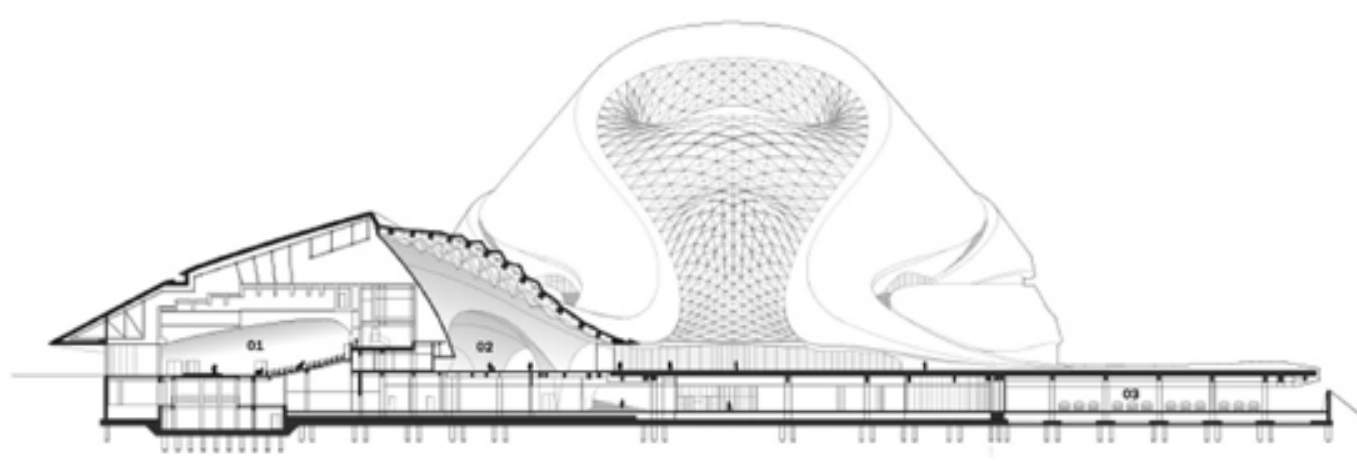

Fig. 2. Cross-section of the Harbin Opera House building. Drawing of the architectural bureau "MAD Architects"

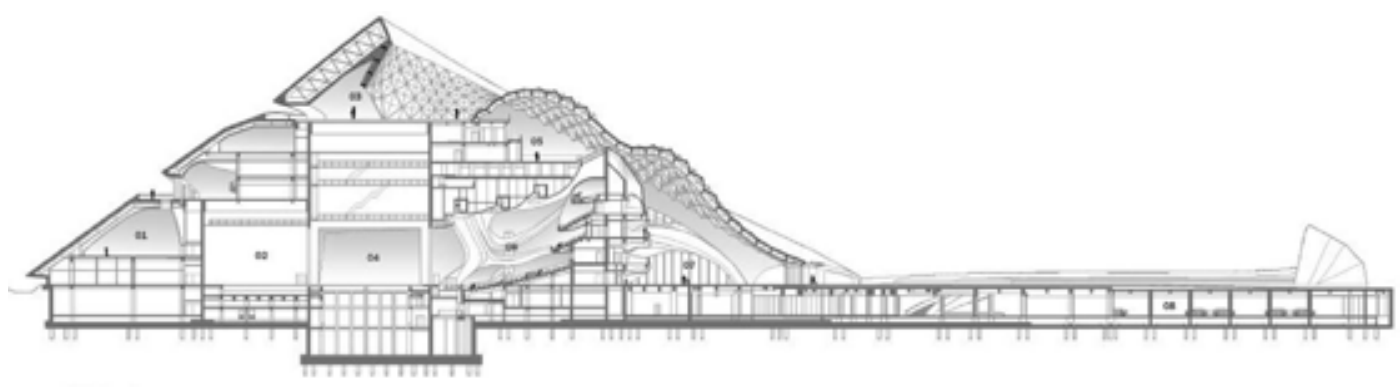

Fig. 3. Longitudinal section of the Harbin Opera House building. Drawing of the architectural bureau "MAD Architects"

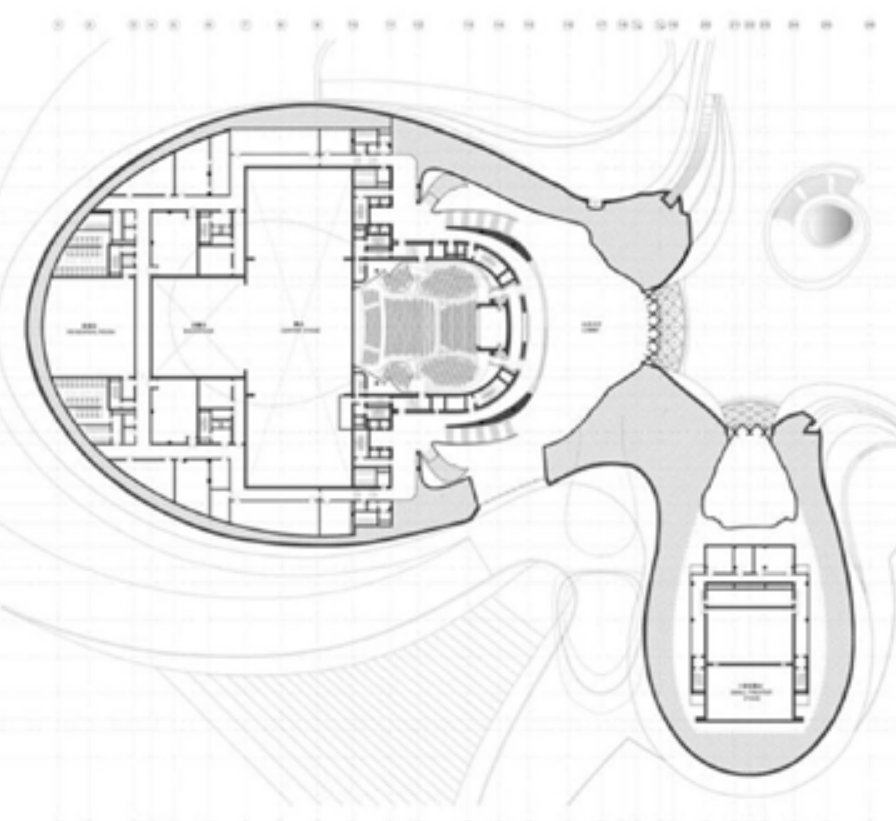

Fig. 4. Second floor plan of the Harbin Opera House building. Drawing of the architectural bureau "MAD Architects" 
mendous performance venue, as well as a dramatic public space that embodies the integration of human, art and city identity."

Despite an abundance of curvilinear forms, prevailing both in the exterior and interior of the building, the stage space, as a whole, has a traditional form; it was designed according to the type of a proscenium stage (resembling the character 品 - pǐn - "product”, "master peace") implying a large free space above the stage, intended for a change of decorations, raising and lowering curtains and lighting fixtures. Sizes of the central stage space reach $32.4 \mathrm{~m}$ in length, $25.5 \mathrm{~m}$ in width (beam span), $50 \mathrm{~m}$ in height, side stage spaces $-25.5 \mathrm{~m}$ in length, $21.9 \mathrm{~m}$ in width (beam span), $19.2 \mathrm{~m}$ in height, back stage space $-24.6 \mathrm{~m}$ in length, $22.5 \mathrm{~m}$ in width (beam span), $20.25 \mathrm{~m}$ in height. The length of the small auditorium span amounts to 25.75 m. (Fig. 5).

A lifting mechanism designed by Beijing New Era Architectural Design Ltd. (Ch. 北京 新纪元建筑工程设计有限公司) was placed into the technology space under the stage (hold) with height $15 \mathrm{~m}$. The stage mechanics uses the following types of the lifting mechanisms: screwing (a "screw-nut" system with an electric drive, where the rise is carried out by the motion of a screw on the inner thread of a nut), hydraulic (a system of cylinders with pistons moving inside them), pushing chain (the Linklift, Serapid systems that consist of two rows of chain links laid into a cassette, which are winded up by the drive gear), spiral (the Spiralift system that has steel strips in the base: narrow strips with a serrated edge and wide strips with a perforated edge, where the rotor mechanism spirally unwinds the strips). In this case, the hydraulic system was used (Fig. 6).

Unusual interiors perception is formed by a sharp contrast between the rich texture of natural wood and white surfaces of the floor and walls. The walls are finished using gypsum cardboards, and the floor - using a tile with natural stone effect. The large auditorium interior is decorated using wooden panels GRG of a curved form. The interior design was developed by Harbin Weimeiyuan Decoration Design Co., Ltd. (Ch. 哈尔滨唯美源装 饰设计有限公司), acoustic calculations were made by Acoustic and Theatre Special Design \& Research Studio of East China Architectural Design \& Research Institute (ECADI) (Ch. 华 东建筑设计研究院有限公司声学及剧院专项 设计研究所), lighting design - by China International Engineering Design \& Consult Co., Ltd. (Ch. 中外建工程设计与顾问有限公司) (Fig. 7-9).

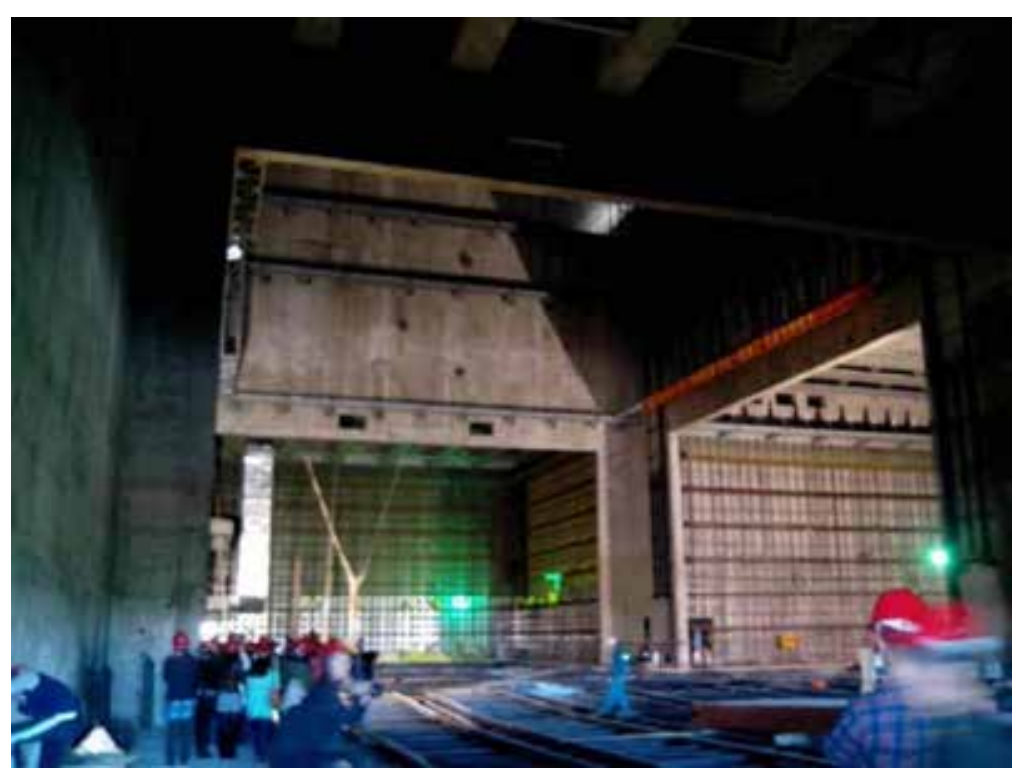

Fig. 5. Construction works inside the stage space. Author's photo, October 2014 


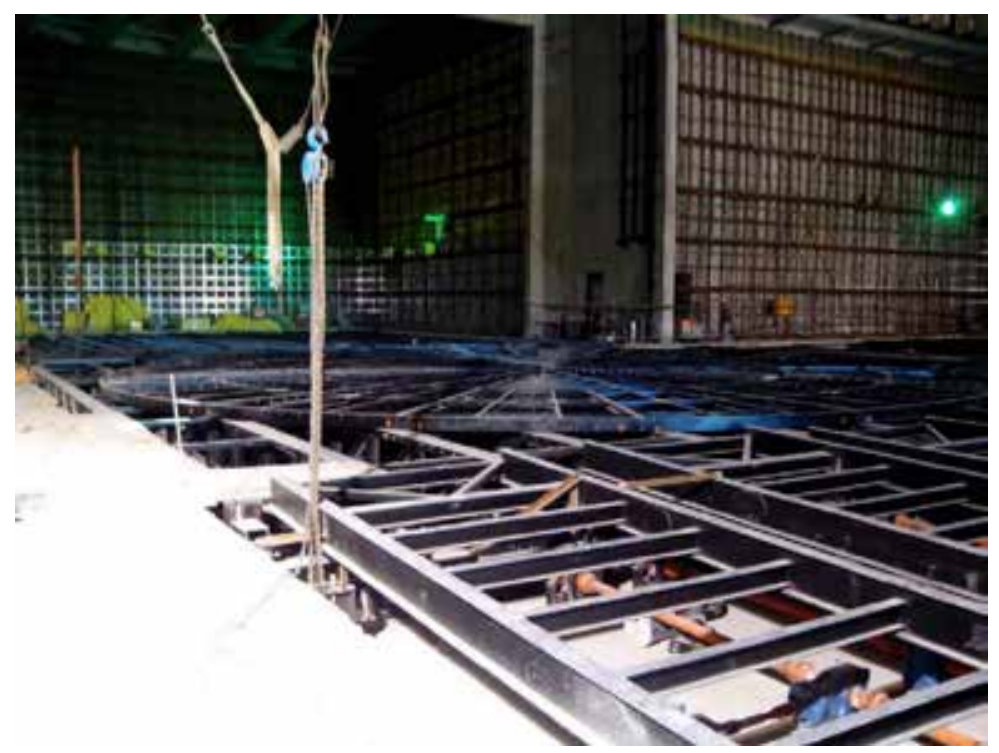

Fig. 6. Automated stage structure. Author's photo, October 2014

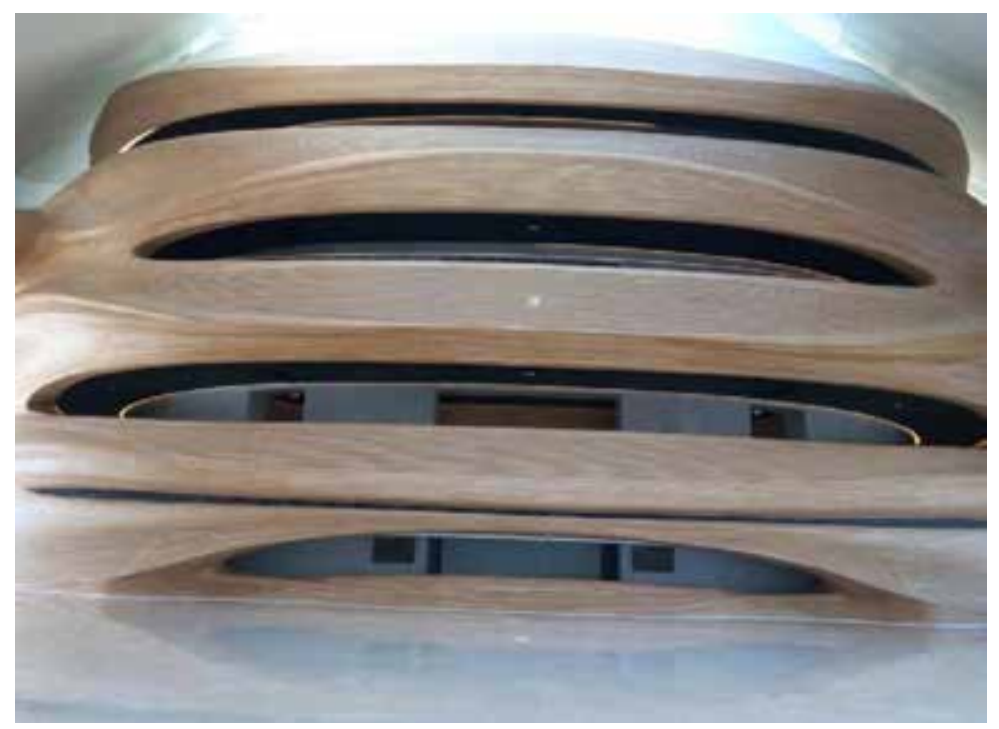

Fig. 7. Lobby zone in front of the large auditorium. Author's photo, September 2015

\section{Structural solutions}

Complex curvilinear structures of the theatre building were formed by the connection of straight, predominantly tubular section elements. Cross-sectional areas reach a maximum value in maximum stress zones - in the base of the building. The advantage of the tubular sectional elements is the sameness of an inertia moment on the axis OX and the axis OY. It sig- nificantly simplifies the calculation. The transition of internal forces is carried out through ball joints (Ch. 焊接球节点) implemented using the low-temperature welding technology in carbon dioxide, which allows to connect elements without melting of the base metal. Lower welding temperature varies in the range $750^{\circ}$ $950^{\circ}$, reducing the possibility of deformation or cracking. Structures with a minimal stress 


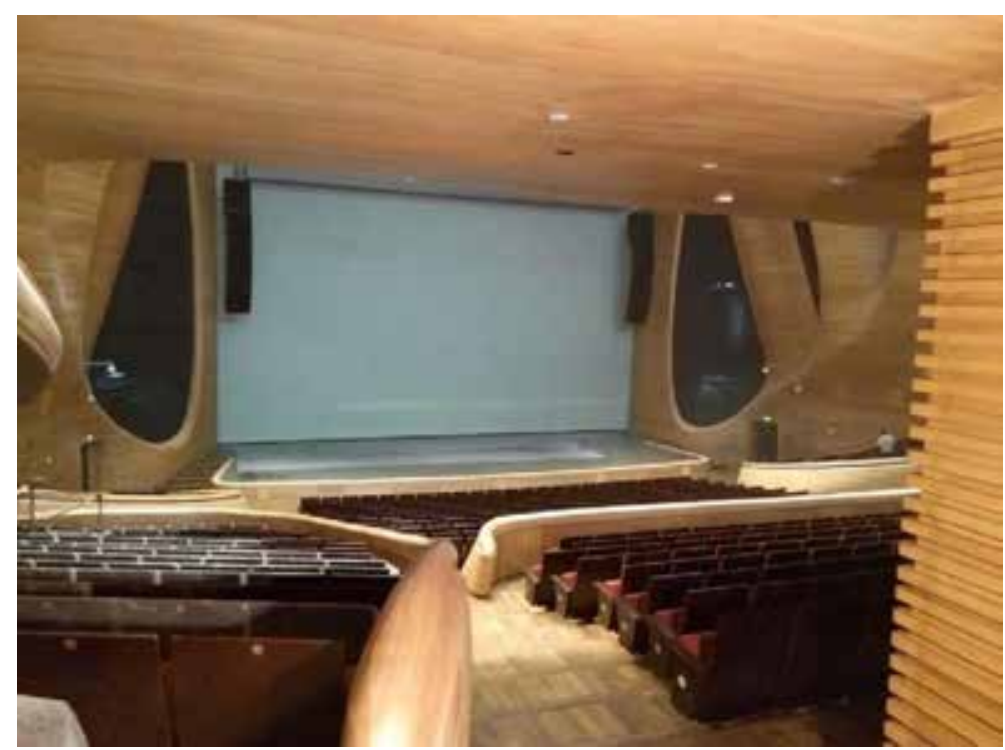

Fig. 8. Interior of the large auditorium. Author's photo, September 2015

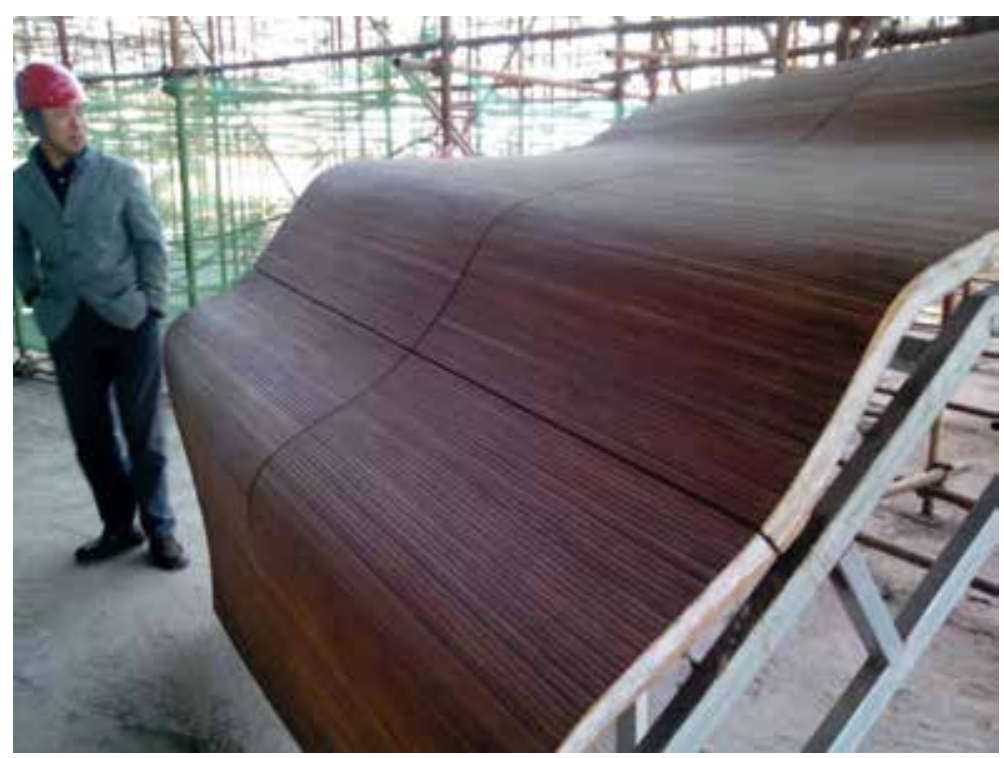

Fig. 9. Large auditorium decoration fragment - a hanging curved wooden panel. Author's photo, October 2014

are located in the front part of the building and were made using I-section elements with welded and bolted connections. (Ch. 螺栓节点) (Fig. 10-12).

Spatial metal structures of the theatre are based on the rectangular pylons that consist of the welded tubular section elements. Vertical elements reach $500 \mathrm{~mm}$ in diameter, $1.0 \mathrm{~m}$, $1.5 \mathrm{~m}, 2.0 \mathrm{~m}, 3.0 \mathrm{~m}$ in length; pipe thickness is $3.1 \mathrm{~mm}( \pm 0.15 \mathrm{~mm})$, steel grade $-\mathrm{Q} 345 \mathrm{~B}$. Horizontal elements are $250 \mathrm{~mm}$ in diameter, $0.6 \mathrm{~m}, 0.9 \mathrm{~m}, 1.2 \mathrm{~m}, 1.5 \mathrm{~m}, 1.8 \mathrm{~m}$ in length, pipe thickness is $2.75 \mathrm{~mm}( \pm 0.275 \mathrm{~mm})$, steel grade - Q235B. Inclined elements, giv- 


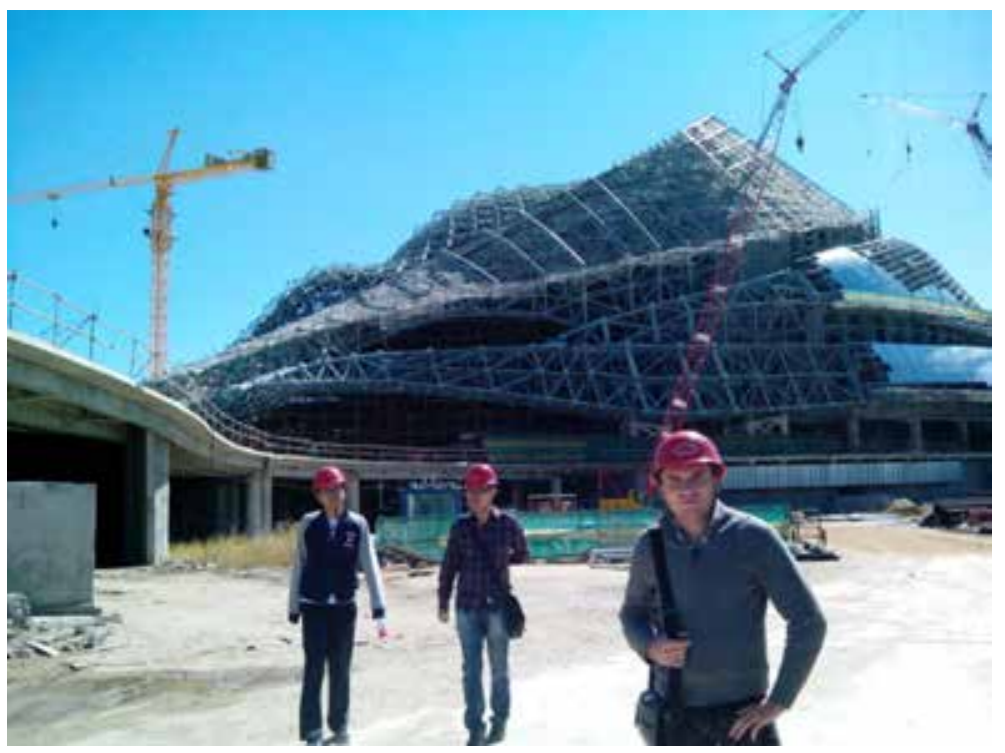

Fig. 10. Harbin Opera House construction process. Author's photo, October 2014

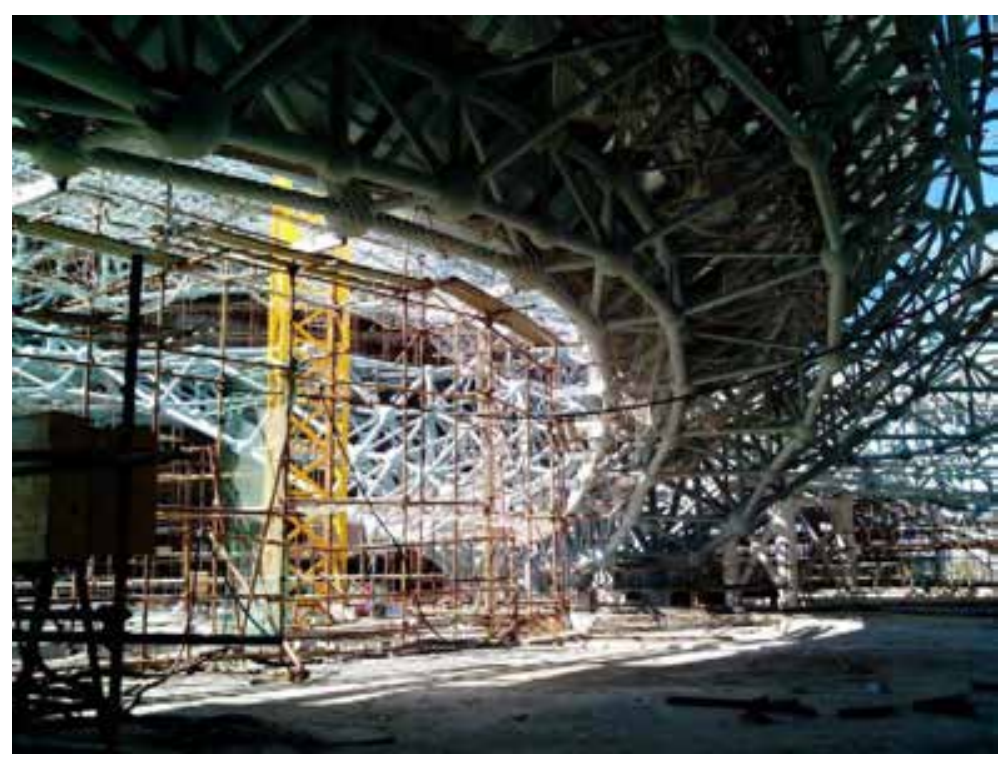

Fig. 11. Inclined arch structure using straight elements. Author's photo, October 2014

ing the structure a bigger spatial rigidity, reach $250 \mathrm{~mm}$ in diameter. They are located in sections with sizes $0.6 \times 1.0 \mathrm{~m}, 0.6 \times 1.5 \mathrm{~m}$, $0.9 \times 1.0 \mathrm{~m}, 0.9 \times 1.5 \mathrm{~m}, 1.0 \times 1.5 \mathrm{~m}, 1.5 \times 1.5 \mathrm{~m}$, $1.8 \times 1.5 \mathrm{~m}, 2.4 \times 1.5 \mathrm{~m}$, pipe thickness is $2.75 \mathrm{~mm}$ $( \pm 0.275 \mathrm{~mm})$, steel grade $-\mathrm{Q} 235 \mathrm{~B}$. The pylons are installed on a reinforced concrete base. It undertakes compression, bending, torsion.
(Fig. 13) The pylons installation works have been carried out from the $4^{\text {th }}$ to the $28^{\text {th }}$ of August, 2011. During testing structures have demonstrated high strength (End of the steel construction..., 2013).

The size of beams over the central stage reaches $800 \times 2500 \mathrm{~mm}$, each beam has 125 tonnes weight. The size of beams over the 


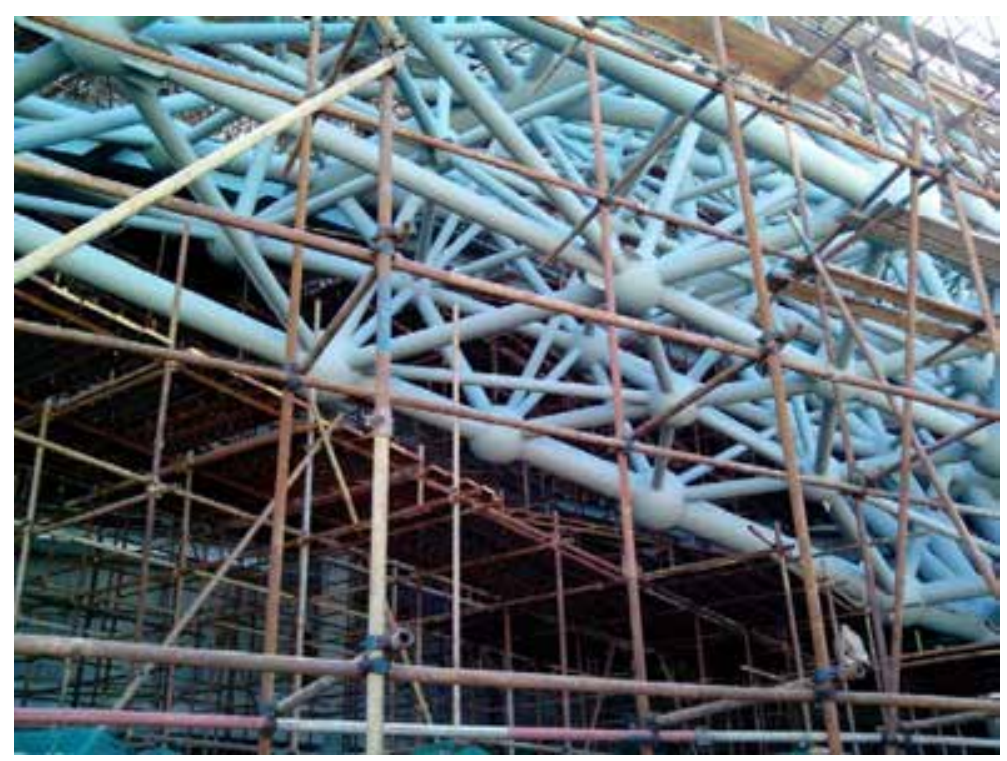

Fig. 12. Ball joint connections. Author's photo, October 2014

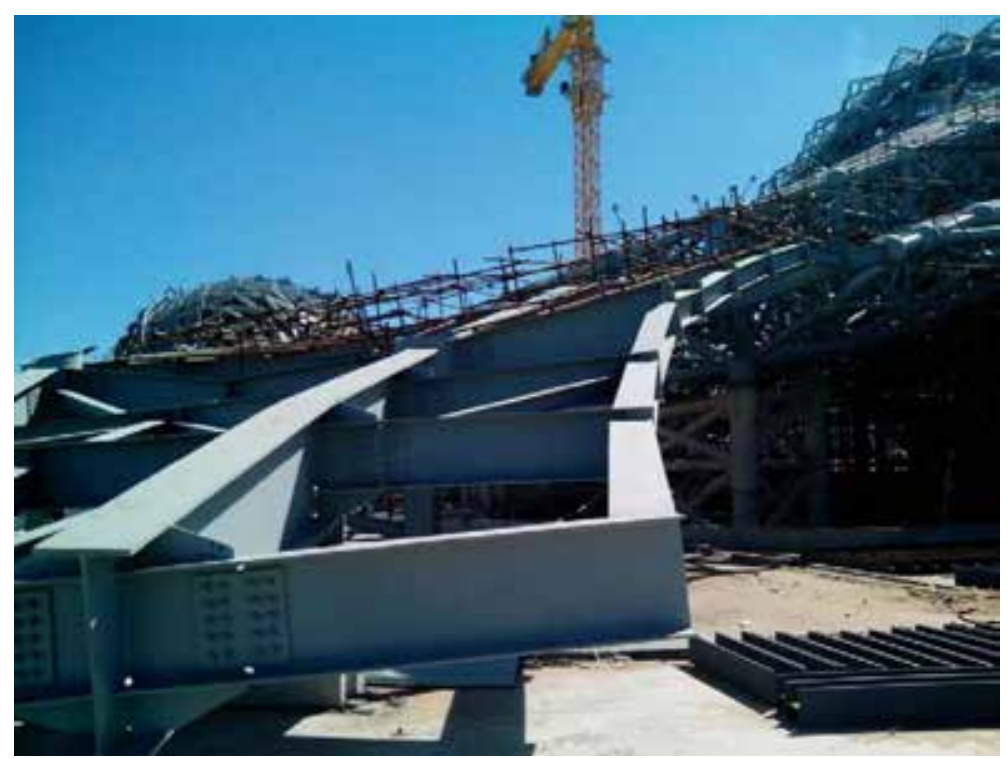

Fig. 13. Curvilinear form structure of I-section elements. Author's photo, October 2014

side stages is $1000 \times 3500 \mathrm{~mm}$, each beam has 190 tonnes weight. The size of beams over the back stage is $800(600) \times 2500 \mathrm{~mm}$, each beam has 135 tonnes weight. All beams were made from reinforced concrete, the slab thickness is $180 \mathrm{~mm}$. The most massive reinforced concrete beam located under the stage is $4.2 \mathrm{~m}$ in height, reinforcement diameter is $40 \mathrm{~mm}$, weight is about 300 tonnes. The total number of embedded fittings exceeds 2000, the weight of the heaviest one is 1.5 tonnes.

The most difficult part of the construction works is the installation of the overlap structure over the large auditorium, which has a span of $32.78 \mathrm{~m}$. The overlap structure consists of six steel compound beams installed in the 
cross direction to the auditorium - two beams with sizes of $\mathrm{H} 2600 \times 700 \times 40 \times 80$, each beam has 56 tonnes weight, four beams with size of $\mathrm{H} 2600 \times 400 \times 40 \times 80$, each beam has 46 tonnes weight. The bottom of the overlap structure is located at the $23.050 \mathrm{~m}$ height. The large auditorium is $37 \mathrm{~m}$ in length, $32 \mathrm{~m}$ in width (beam span), $27 \mathrm{~m}$ in height. The beams material is the steel grade Q345GJC-Z15 and Q345GJC-Z25. Both sides of the beams are fixed with highstrength bolts. The installation of the structural elements was done using crawler cranes (履 带式重机) with lifting capacity of 400 tonnes and a hook with maximum reach of $96 \mathrm{~m}$, and also using a rails laid on a concrete base, on which the heaviest structural elements took their design position (The official website of the architectural...). The lower floors structures were made from reinforced concrete - cylindrical columns, beams of rectangular section (Fig. 14).

The structural calculations were made by Gehry Technologies Co., Ltd (Ch. 锃利科技 有限公司) based on the model designed using the Rhinoceros software mainly intended for the three-dimensional visualization. Its important feature is the ability to design using vector graphics, which allows converting the model into other formats, without breaking the form into separate elements, saving original dimensions (Aigner, Brell-Cockan, 2009).
The project design also used AutoCAD drawings of plans, facades, sections, nodes, etc., 3Dmax - for creating presentations and videos (Fig. 15).

Inhabit Group company (Ch. 英海特幕墙 顾问公司) was a consultant for the facade solutions, China Jingye Engineering Co., Ltd. (Ch. 中国京冶工程技术有限公司) - a consultant for facing materials. The covering structure consists of a stainless-steel checker plate and metal profiles for the fixation of the decorative light-grey coloured aluminium panels. Due to the complex curved shape of the building, the joints between the flat rectangular panels are not successfully done everywhere. Defects are particularly evident at the junction of panels with the base of the building, staircases. The total area of the metal covering is $25,000 \mathrm{~m}^{2}$. The cement wall panels also were used for the external facing, the total area of which is $7,400 \mathrm{~m}^{2}$ (Fig. 16).

A tiling method was used in the design of the complex glass covering structure, implying the curvilinear form division on a plurality of separate surfaces, in this case - triangular, with subsequent raise of certain points. The result of modelling is a complex unusual structure that consists of a large number of pyramidal forms. The gutters were constructed on the contour of the glass coverings structure for water runoff. The total area of the glass

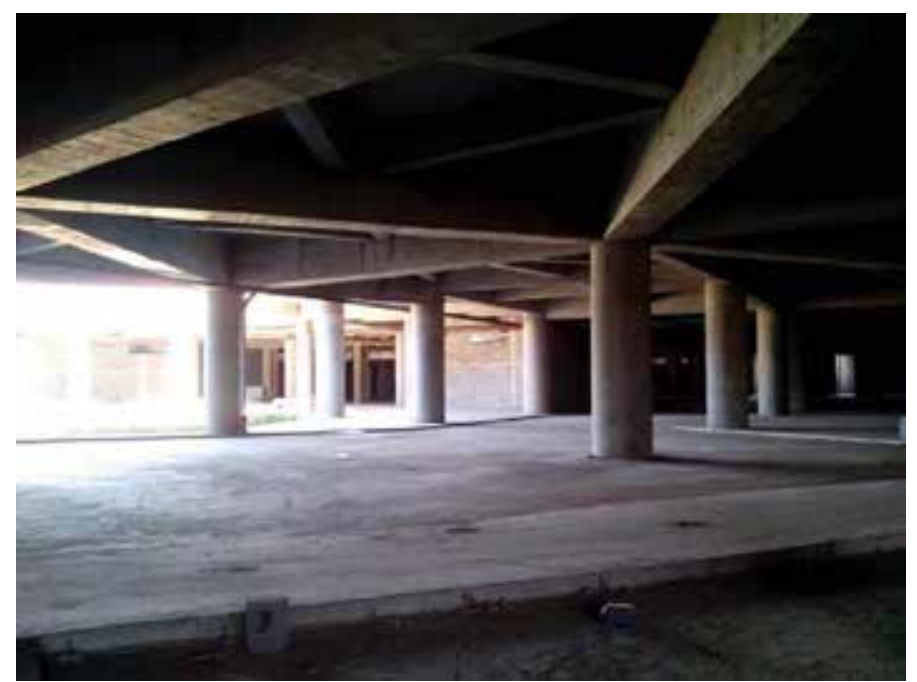

Fig. 14. The lower floors structures. Author's photo, October 2014 


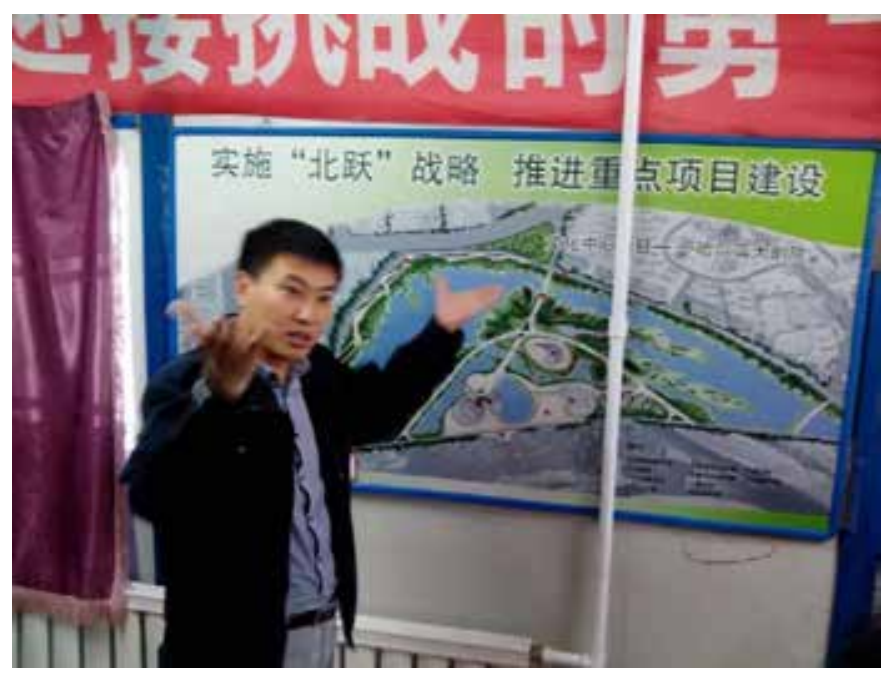

Fig. 15. Representative of the construction company tells about construction works. Author's photo, October 2014

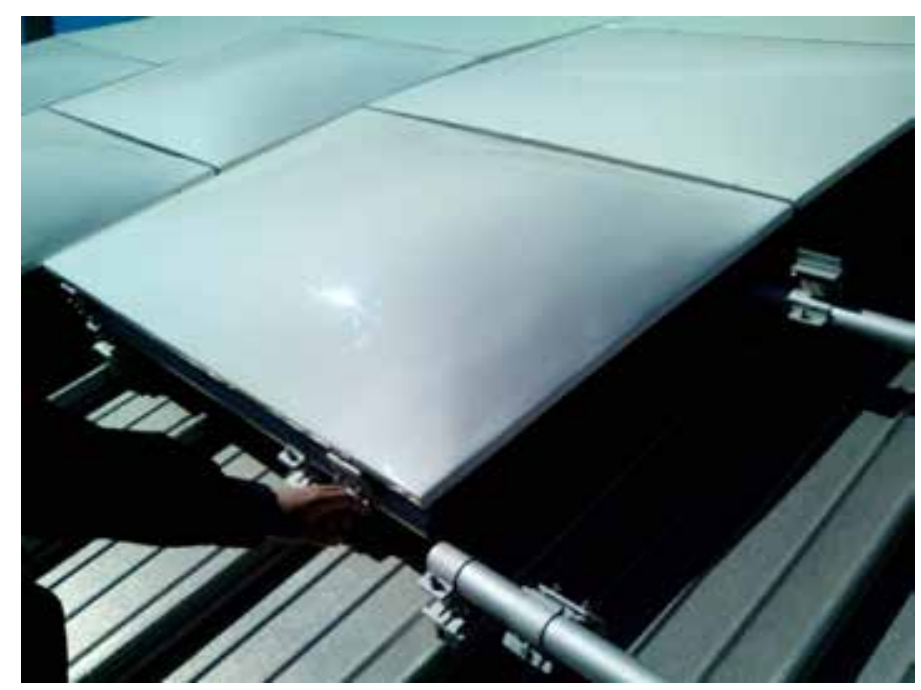

Fig. 16. Metal covering structure. Author's photo, October 2014

structures, including wall panels, is $5,300 \mathrm{~m}^{2}$. The combination of glass material with steel structures is very common in the curvilinear architecture. Previously the complex transparent coverings structure was designed using large triangular panels with a mirror effect. However, subsequently, the large glass panels have been replaced by relatively small ones. The reasons of this decision are: firstly, the installation complexity, secondly, high labour expenses for production (most of the glass panels have individual sizes). As a rule, steel load-bearing structures, on which the glass panels are mounted, remain visually open. A distinctive feature of this project is that the glass panels are located outside of the coverings plane, and the steel structure itself is hidden behind a decorative trim. This solution, on one hand, significantly reduces transparency of the covering structure, which is considered bad, but, on other hand, it gives the structure a special aesthetic effect (Fig. 17). 


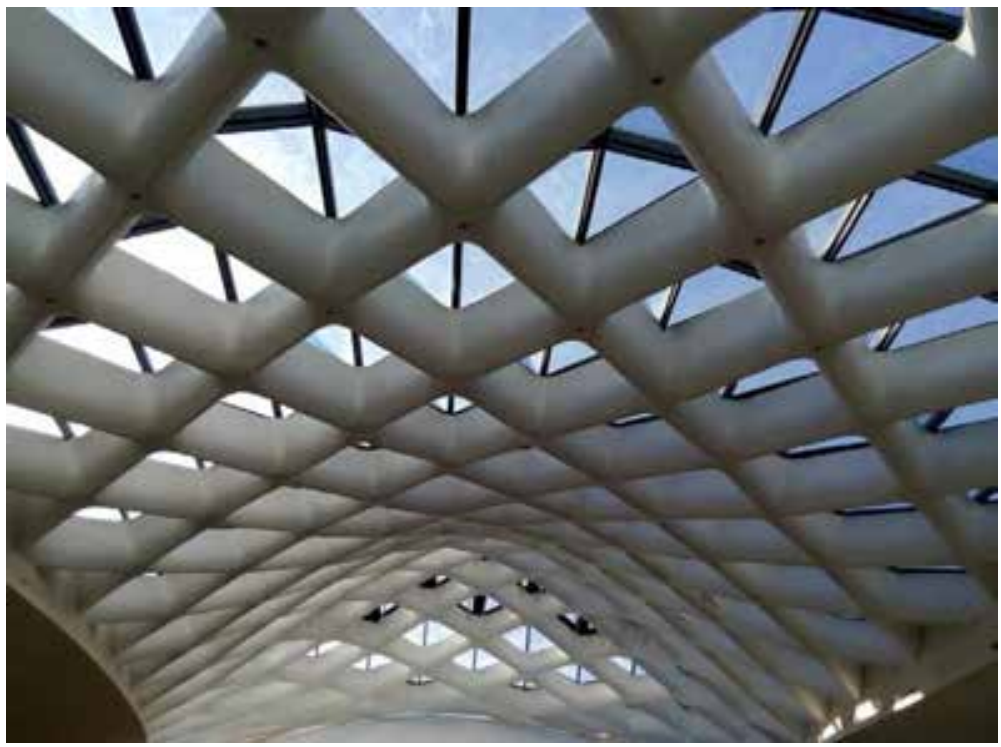

Fig. 17. Glass covering structure. Author’s photo, September 2015

\section{Analysis \\ of the structural solutions}

Despite the abundance of curvilinear forms characteristic of the whole building, the structures of the theatre have a very traditional look, strength and stability of which are achieved by increasing the cross-sectional areas, rigid welded joints, configurations of structural elements in order to increase the moment of inertia. Thus, it leads to emergence of massive bulky structures with a weight of few hundred tons, which do not reduce the labour expenses during the installation, but also significantly increase the cost of the structure. In this case, it was necessary to construct a special mechanism, moving on which the structural elements could reach their own project positions, considering the fact that the span of the large auditorium ( $32.78 \mathrm{~m}$ ) was relatively small. Newest technologies allow constructing buildings with a span significantly exceeding $100 \mathrm{~m}$ with a more economic effect.

The building structures, mainly formed using welded joints, have a very low repairability - structural elements are very difficult or almost impossible to completely replace in the cause of moral or physical deterioration. The building, in whole, has a fairly high level of fire risk. The decorative hanging wood pan- els of the large auditorium interior, lobby zone and other spaces are easily inflammable. At high temperatures, steel structures are rapidly losing their load-bearing capacity. Therefore, the steel structure elements require additional fire protection measures. The structure surfaces should not be open.

The Opera House is located in a region with a severely continental climate, where the absolute value of the minimum temperature in winter reaches $-40.1{ }^{\circ} \mathrm{C}$. Daily temperature fluctuations often account for more than $20{ }^{\circ} \mathrm{C}$. The use of steel as the main material of the structure due to its high thermal conductivity promotes the formation of numerous cold bridges. Due to the lack of compliance of connected nodes and special deformation seams, a rigid metal framework is almost deprived of the opportunity to perceive thermal deformations, thus, there is a huge amount of unnecessary stress that significantly reduces durability of the structure.

The theatre structures would be more optimal, if, for example, the bulky metal framework playing the role of the main bearing element was replaced by thin-shell structures, that, reducing material expenses, make internal forces transition more effective, significantly increasing the interior space. The thin- 
shell structures' rigidity is achieved exactly by curvilinearity.

As a rule, architects strive to introduce newest innovative materials for the special, unique objects design, however, the Harbin Opera House project uses quite usual aluminium panels for the facade facing, usual steel materials for the framework structures, chosen according to the Chinese standards, as well as quite usual decoration materials (wood, gypsum cardboard, tiles) for the interior design.

A lot of structural solutions implemented by the architectural bureau "MAD Architects" also were realized in the project of China Wood Sculpture Museum in Harbin (Ch. 哈尔滨木头雕塑博物馆), Jun Li district (Ch. 军力). This project is also distinguished by the rich content of curvilinear forms. It has been realized in period from 2009 to 2013.

\section{Conclusion}

Unfortunately, the level of technical skills, especially regarding the construction of complex, unique objects, is still very low today. The lack of engineering knowledges of architects, as well as the lack of architectural knowledge of engineers are a very common problem in contemporary architecture. It is absolutely obvious that the use of traditional types of structures for the realization of "ultra-modern" sophisticated forms is totally wrong. The curvilinear architecture, by the way, as any other, needs to develop its own, individual structural solutions. In the case of Harbin Opera House, huge opportunities that curvilinear form design has were not used. The structures, hidden behind a decorative trim, are almost completely devoid of any kind of aesthetic expression, and the external shapes formed by these structures are devoid of any meaningful content. American architect Greg Lynn notes that the result of the curvilinear form design is "out of formalism into a world of external influences", "it is important to maintain a logic rather than a style of curvilinearity." (Januszkiewicz, Banachowicz, 2016) It is difficult to disagree with these words. It is also important to understand that the architect's attention should be focused not only on the creation of a strange kind of external forms, but also on the structure of the designed object, because the final result directly depends on the architect's ability to find the conformity between the form and its content.

\section{References}

Adnan, F., Mohd Yunus, R. (2012). The Influence of Curvilinear Architectural Forms on Environment-Behaviour. Procedia - Social and Behavioural Sciences, 49, 341-349.

Aigner, A., Brell-Cockan, S. (2009). Surface Structure and Robot Milling. The Impact of Curvilinear Structured Architectural Scale Models on Architectural Design and Production. Innovative Design \& Construction Technologies - Building complex shapes and beyond. Vienna University of Technology, 1-12.

Deleuze, G. (1997). The Fold. Leibniz and the Baroque. Logos. 171-172.

End of the steel construction works of the Harbin Opera House (哈尔滨大剧院完成钢结构建设) (2013). Steel structure (钢结构). (168), 94.

Han Peng (韩朋). (2012). Construction Technique on Huge Steel Beam Out-span Lifting Technique and Thick Plate Low-Temperature Welding Technique in Harbin Grand Theatre Project (哈尔滨大剧院巨型钢 梁夸外吊装与厚板低温焊接技术研究). Architecture Technology (建筑技术), 43(5), 394-397.

Januszkiewicz, K., Banachowicz, M. (2016). Glass as a Component of Curvilinear Architecture in $21^{\text {st }}$ Century. Procedia Engineering, 161, 1490-1495.

Kurshakova, V. Problems of application of the newest membrane structures in contemporary architecture. Architecton: Proceedings of the universities (22/2008), Ural State University of Architecture and Art. Available at: http://archvuz.ru, Access date: 17 January 2017.

Lynn, G. (1993). Architectural Curvilinearity. The Folded, the Pliant and the Supple. Architectural Design. 63 (3/4). Folding in Architecture. Willey Academy, 24-31. 
Pan Haixu (潘海迅), Sun Yu (孙宇). (2006). Architecture Curve and Colony Design (建筑曲线与群体 设计). World Architecture (世界建筑), (6), 93-95.

The official website of the architectural bureau "MAD Architects". Available at: http://www.i-mad. com/work/harbin-cultural-center, Access date: 18 January 2017.

\title{
Архитектурная криволинейность - анализ конструктивных решений Харбинского оперного театра
}

\author{
И.В. Киричков \\ Сибирский федеральный университет \\ Российская Федерачия, Красноярск \\ Сибирский государственный институт искусств \\ имени Дмитрия Хворостовского \\ Российская Федерачия, Красноярск
}

\begin{abstract}
Аннотация. В настоящее время криволинейная архитектура стремительно развивается во многих странах мира. В данной научной статье кратко описаны методы создания криволинейных строительных конструкций, названы их достоинства и недостатки. Был проведен анализ конструктивных решений одного из самых уникальных произведений современной архитектуры - Харбинского оперного театра, спроектированного китайским архитектором Ма Янсоном. Результат более чем пятилетних исследований показал, что уровень технических навыков, особенно связанных со строительством сложных, уникальных объектов, к сожалению, все еще остается низким. Огромные возможности создания форм складчатого формообразования не были использованы. Традиционный подход к архитектурному дизайну, в том числе к современным методам создания форм, ошибочен. Криволинейная архитектура, как и любая другая, нуждается в разработке собственных, индивидуальных конструктивных решений.
\end{abstract}

Ключевые слова: криволинейность, пространственные конструкции, Харбинский оперный театр, морфогенез, складчатые формы, современная архитектура, складка.

Научная специальность: 05.23.20. - теория и история архитектуры, реставрация и реконструкция историко-архитектурного наследия. 